\title{
Pemberdayaan Forum Pemuda Lintas Agama (FPLA) dalam Penguatan Kapasitas Anggota Sebagai Aktor Penggerak Toleransi di Kabupaten Kulon Progo Yogyakarta
}

\section{Syafi'ie' ${ }^{1}$, Alif Lukmanul Hakim² ${ }^{2}$ Despan Heryansyah ${ }^{3}$}

1) Dosen FH dan Pusat Studi Hak Asasi Manusia (PUSHAM) Universitas Islam Indonesia Yogyakarta

2) Dosen FTI Universitas Islam Indonesia Yogyakarta

3) Pusat Studi Hak Asasi Manusia (PUSHAM) dan Mahasiswa Program Doktor Fakultas Hukum Universitas Islam Indonesia Yogyakarta

M Email : m.syafiie@uii.ac.id

\begin{tabular}{l|l|l} 
Received: 01-02-2021 | Revised: 21-03-2021 | Accepted: 12-04-2021 & |
\end{tabular}

\begin{abstract}
:
Indonesia is a country built on the foundation of multiculturalism. Since the beginning, the founders of this Republic were aware of this, so that the first principle of Pancasila reads God Almighty. This is an important indication that Indonesia is not a religious state, all religions before the state have the same and equal position. The state, in fact, guarantees all citizens to be free to worship according to their respective religions and beliefs. However, the life of the nation, state and society in a concrete sense is not always as good as it is conceived. In practice, religious primordialism, religious fundamentalism, and even radicalism still frequently occur. According to certain religious teachings, this group isolates, or even is hostile to, adherents of other different religions. The forms of this movement vary, from the most violent in the form of acts of terrorism, to the most gentle in the form of rejection of other parties who are different. Young people who have just entered high school and university are easy targets of this movement. Whereas in fact, the Indonesian nation from a cultural historical aspect, is a nation that loves harmony, a nation that respects and respects differences, united in the spirit of mutual cooperation. However, the spirit or soul is often covered by the massive fundamentalism movement carried out by this particular group. Therefore, departing from the above problems, we are collaborating with the Kulon Progo Interfaith Youth Forum (Forum Pemuda Lintas Agama) to organize activities that can foster unity and tolerance, especially among youth in Kulon Progo. Kulon Progo is used as an object because it is in a transition period to become an urban area, which of course there will be many identity intersections in the community. The activity was successfully held for two online discussions. The first discussion discussed tolerance and harmony between religions in a more general context. How is the situation in the world and in Indonesia itself. This was followed by a second discussion by presenting representatives from several religions, to convey the perspective of tolerance from their respective religious teachings.
\end{abstract}

Keyword: Interfaith, Tolerance, Youth

\section{Pendahuluan}

Sejak awal berdirinya NKRI, founding people negeri ini sepenuhnya menyadari bahwa Indonesia adalah negara yang plural atau beranekaragam (Azyumardi Azra, Jakarta: Paramadina, 1996, ii). Komitmen atas kesadaran itu, sesungguhnya secara sosio-politis telah terangkum di dalam Sumpah Pemuda 28 Oktober 1928. Bagaimana mungkin, sekelompok pemuda dengan penuh kesadaran menyatukan dirinya dalam rumpun satu bangsa, satu tumpah darah, dan satu bahasa, 
padahal Indonesia sendiri sebagai sebuah identitas negara belumlah lahir. Nyaris tidak ada egoisme pemeluk agama yang muncul ketika itu, meski dalam hal gerakan sudah ada Serikat Islam yang lahir pada 1912, pula tidak ada egoisme kesukuan meski telah ada Budi Utomo yang notabennya adalah suku Jawa telah ada sejak 1908.

Komitmen kedua dilakukan pada saat pemimpin bangsa ini mengesahkan Pembukaan UUD Negara Republik Indonesia Tahun 1945, dengan mengganti tujuh huruf dalam Piagam Jakarta (Jakarta Charter), Ketuhanan dengan Kewajiban Menjalankan Syariat Islam bagi PemelukPemeluknya menjadi Ketuhanan Yang Maha Esa. Bagi golongan Islam sendiri pilihan ini tidaklah mudah, namun pengorbanan atas nama persatuan Indonesia dirasakan jauh lebih penting ketimbang ego sektoral menerapkan syariat Islam. Ki Bagus Hadi Kusumo menyebut sila pertama sebagai "Tauhid", yang posisinya jauh lebih tinggi dari pada sekedar syariat (Lihat John L. Esposito dan John O. Voll, 1999: 3).

Pengalaman membuktikan bahwa kubangan primordialisme dalam bentuk keinginan satu suku untuk mendominasi suku yang lain serta fundamentalisme agama dalam bentuk perasaan kelompok agama (Islam) untuk menerapkan syariat Islam di Indonesia adalah tantangan besar bangsa ini sejak awal bedirinya (Bahtiar Efendi, Jakarta: Paramadina, 1998). Meskipun secara filosofis, Fundamentalisme agama sejatinya telah dijawab oleh sila "Ketuhanan Yang Maha Esa", bahwa negara Indonesia bukanlah negara agama, melainkan negara yang melindungi kebebasan beragama dan berkeyakinan seluruh warga negara. Sedangkan Primordialisme telah terakomodir dalam sila "Persatuan Indonesia", bahwa semua suku memiliki hak dan kedudukan yang sama, yang oleh karenanya tidak boleh ada dominasi dari satu ke yang lain.

Harus diakui bahwa eksistensi Indonesia sebagai sebuah bangsa maupun negara masih tetap bertahan sampai hari ini, adalah karena kemampuan untuk mendamaikan dan menekan seminimal mungkin letupan yang diakibatkan oleh fundamentalisme agama dan primordialisme kesukuan. Catatan sejarah menunjukkan bahwa gerakan untuk memisahkan diri dari Indonesia karena keinginan untuk mendirikan negara Islam atau atas dasar kesukuan sudah berulang kali terjadi. Meskipun selalu mengalami kegagalan, yang lebih karena disebabkan oleh kekuatan persenjataan tentara Indonesia.

Di era milenal ini, gerakan separatisme untuk memisahkan diri dari Negara Kesatuan Indonesia memang sudah tidak terdengar, baik yang mengatas namakan agama maupun kesukuan (Dedy Djamaluddin Malik dan Idi Subandy Ibrahim, Bandung, 1997, 34). Pemerintah Indonesia selalu berhasil menangani dengan tanggap dan tegas berbagai isu separatisme yang berpotensi mengganggu keutuhan NKRI. Namun demikian, gerakan-gerakan radikalisme dengan berbagai bentuknya dan primordialisme bukan berarti sudah tidak ada sama sekali, dalam beberapa tahun terakhir justeru semakin menguat meskipun dengan gerakan yang lebih soft. Pilkada Jakarta misalnya, menyisakan ingatan kita tentang menguatnya kembali fundamentaslisme agama, yang hari ini telah masuk pada hampir seluruh aspek kehidupan berbangsa dan bermasyarakat. Primordialisme sendiri semakin menguat misalnya ajakan untuk memilih putra daerah dalam pilkada, atau penolakan terhadap salah satu etnis tertentu untuk menjadi kepala daerah. Bahkan terakhir, peristiwa yang terjadi di Malang dan Wamena menunjukkan bahwa ikatan nasionalisme kita sebagai sebuah bangsa, masih harus diperjuangkan. Namun demikian, primordialisme ini, memang hanya terjadi di beberapa daerah saja, berbeda dengan isu radikalisme yang menjangkiti seluruh daerah di Indonesia.

Konteks yang lebih memilukan sekaligus memalukan adalah radikalisme itu kerap dimanfaatkan untuk kepentingan politik dan ekonomi elit tertentu. Dalam beberapa hasil pengabdianan Pusham UII yang telah diterbitkan menjadi buku, menunjukkan bahwa hampir 
semua konflik antar agama yang terjadi di Medan, Jawa Barat, Sulawesi, dan Jogjakarta adalah disebabkan oleh kuatnya arus persaingan elit politik lokal menjelang pilkada. Ada konvergensi yang tepat antara radikalisme di satu sisi serta kepentingan politik dan ekonomi pada sisi yang lain. Konvergensi ini, yang meskipun dilakukan atas nama demokrasi namun kerap justeru melanggar prinsip-prinsip demokrasi dan hak asasi manusia itu sendiri (Nurcholish Madjid, Jakarta: Paramadina, 1999).

Memang harus diakui, bagi kelompok yang memang sudah memiliiki sikap radikal, sangat sulit untuk mengubahnya, bahkan justeru radikalisme itu tak jarang berkembang menjadi terorisme. Namun, ada generasi lain yang patut menjadi perhatian agar tidak terjangkit oleh sikap radikalisme, yaitu generasi muda atau generasi mileneal Indonesia. Secara universal, menangkal gerakan radikalisme itu tidak lain adalah dengan menanamkan nilai-nilai Pancasila. Namun penanamannya tidak dapat dilakukan dengan model doktrinasi seperti pada masa lalu, generasi milenial ini dihadapkan pada situasi dan tantangan yang berbeda, oleh karena itu pendekatannya pun harus berbeda.

Berangkat dari isu tersebut, Pusham UII pada tahun 2018, mencoba untuk menjalankan satu program di Yogyakarta, tepatnya di Kabupaten Kulon Progo. Alasan memilih Kulon Progro adalah karena pembangunan Bandara YIA menjadikan Kulon Progra sebagai kabupaten transisi menuju perkotaan, maka dapat diprediksi akan banyak pendatang baru dengan latar belakang identitas yang berbeda-beda. Program tersebut pada intinya adalah memperkuat jaringan antara pemerintah daerah, Forum Kerukunan Umat Beragama (FKUB), Kepolisian, dan organisasi masyarakat sipil. Salah satu output dari projek tersebut adalah membentuk Forum Pemuda Lintas Agama (FPLA), yaitu organisasi kepemudaan yang diisi oleh perwakilan dari masing-masing agama yang ada di Kulon Progo, yang tujuan utamanya adalah memperkuat toleransi di Kulon Progo. FPLA merupakan perpanjangan tangan dari FKUB yang secara khusus berfokus pada para pemuda.

Apa yang Pusham UII lakukan untuk membangun FPLA juga sangat sederhana, yaitu melakukan perjumpaan-perjumpaan informal antara para pemuda lintas agama, sehingga mereka menjadi saling kenal dan membangun komitmen bersama akan pentingnya toleransi di Kulon Progo. Saat ini, FPLA sudah terbentuk dan memiliki program kerja tersendiri. Program kerja dibuat menjadi sederhana, yang terpenting menunjukkan nilai-nilai kebersamaan. Misalnya: dialog inteaktif yang dilakukan di salah satu gereja di mana pesertanya juga dihadiri oleh pemuda dari agama-agama yang lain, kunjungan ke salah satu pesantren di Kulon Progo, even kebudayaan yang mengusung tema kerukunan umat beragama, dan lain sebagainya.

Singkatnya, FPLA saat ini menjadi motor penggerak toleransi di Kulon Progo, karena dijalankan oleh pemuda-pemudi lintas agama, sehingga gerakannya sangat kental dengan ide-ide milenial. Namun demikian, saat ini FPLA di Kulon Progo masih sangat membutuhkan dorongan program, selain untuk meningkatkan kapitas anggota juga untuk mendukung program kerja FPLA mendatang. Selama ini, karena FPLA terhitung baru, dukungan anggaran yang didistribusikan oleh pemerintah daerah masih terbatas. Oleh karena itu, Pusham UII bekerjasama dengan DPPM UII mengadakan pengabdian mendukung penguatan kapasitas Anggota FPLA dan program kerja FPLA. 


\section{Metode Pelaksanaan}

\section{Metode Pelaksanaan}

Untuk mengatasi berbagai masalah di atas, maka kegiatan yang diselenggarakan dalam pengabdian ini adalah sebagai berikut:

1. Kegiatan pertama adalah penguatan kapasitas Anggota FPLA melalui seminar online, seminar ini penyampaian materi yang berkaitan dengan pemuda dan toleransi dengan jumlah peserta 35 orang. Adapun pembicara dalam kegiatan ini adalah tokoh dari lima agama dengan dua orang fasilitator;

2. Kegiatan kedua, masih dalam rangka mendorong program FPLA, yaitu melakukan kunjungan ke rumah ibadah lima agama (Islam, Kristen, Protestan, Hindu, dan Budha) dan berdialog singkat dengan pengelola rumah ibadah. Karena sedang dalam masa pandemi, kegiatan ini diganti dengan dialog online, dimana pembicara merupakan pewakilan dari pemeluk agama Islam (Muhammadiyah dan NU) dan pemeluk agama hindu. Kegiatan ini juga diikuti oleh 35 orang peserta ditambah dengan 1 orang fasilitator dan dua orang panitia.

Pelatihan Penguatan Kapasitas bagi anggota FPLA yang diselenggarakan online karena pandemi covid-19

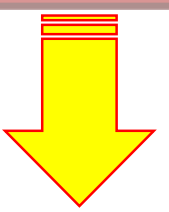

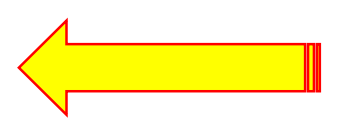

Menyusun metode kegiatan penguatan kapasitas FPLA di Kabupaten Kulon Progo. Kegiatan diselenggarakan dalam bentuk pelatihan dan diskusi

Diskusi dengan perwakilan pemeluk masing-masing agama

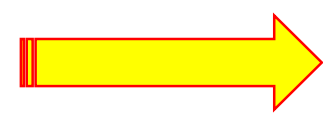

Monitoring dan Evaluasi

\section{Jadwal kegiatan}

Tahapan dan rangkaian program Pengabdian masyarakat dan waktu pelaksanaannya sebagai berikut

\begin{tabular}{|c|c|c|c|c|c|c|c|c|c|c|c|c|c|}
\hline \multirow{2}{*}{ No } & \multirow{2}{*}{ Jenias kegiatan } & \multicolumn{4}{|c|}{ Januari } & \multicolumn{4}{|c|}{ Februari } & \multicolumn{4}{|c|}{ Maret } \\
\hline & & 1 & 2 & 3 & 4 & 1 & 2 & 3 & 4 & 1 & 2 & 3 & 4 \\
\hline 1 & Koordinasi dengan FKUB dan FPLA & & & & & & & & & & & & \\
\hline 2 & $\begin{array}{l}\text { Pembuatan dan Pembagian undangan serta } \\
\text { Persiapan Pelatihan }\end{array}$ & & & & & & & & & & & & \\
\hline 3 & $\begin{array}{l}\text { Pelaksanaan Kegiatan Pelatihan Penguatan } \\
\text { Kapasitas bagi anggota FPLA Kabupaten } \\
\text { Kulon Progo }\end{array}$ & & & & & & & & & & & & \\
\hline 4 & $\begin{array}{l}\text { Pelaksanaan kegiatan diskusi dimana } \\
\text { masing-masing agama berbicara mengenai }\end{array}$ & & & & & & & & & & & & \\
\hline
\end{tabular}




\begin{tabular}{|c|l|l|l|l|l|l|l|l|l|l|}
\hline & $\begin{array}{l}\text { prinsip toleransi menurut agamanya masing- } \\
\text { masing }\end{array}$ & & & & & & & \\
\hline 5 & Monitoring dan evaluasi kegiatan mitra & & & & & & & \\
\hline 6 & Pembuatan Laporan & & & & & & & & \\
\hline 7 & $\begin{array}{l}\text { Medsos, Poster, Proceding dan Jurnal } \\
\text { pengabdian masyarakat atau luaran lainny }\end{array}$ & & & & & & & & \\
\hline
\end{tabular}

\section{Hasil dan Pembahasan}

\section{A. Pelaksanaan Kegiatan}

\section{Seminar Indonesia Satu dalam Keberagaman}

Seminar ini diselenggarakan pada tanggal 16 Januari 2021 secara daring. Peserta berjumlah 35 orang yang semuanya adalah perwakilan dari Forum Pemuda Lintas Agama (FPLA). Kegiatan berlangsung dari pukul 13.00-17.00 WIB. Tema pembicaraan adalah terkait dengan keberagaman dan toleransi. Diskusi mengenai toleransi pada akhir-akhir ini sangatlah mendesak dan penting, karena di banyak tempat sudah banyak muncul tindakan intoleransi yang mengkhawatirkan. Terbukti, konflik berdimensi keagamaan serta pelanggaran kebebasan beragama dan berkeyakinan, mudah ditemukan dan marak terjadi di berbagai wilayah di Indonesia. Harus diakui, Indonesia masih merupakan potential offender dalam isu kebebasan beragama dan berkeyakinan. Kita masih belum sepenuhnya memasuki tahap akil baligh dalam menyikapi perbedaan, terutama menyangkut perbedaan (pandangan) agama, kepercayaan, dan keyakinan. Kita masih alergi dan mudah tersulut rasa amarah dengan sesuatu yang berbeda di luar diri dan kelompok kita: "yang lain", the others, liyan, yang sering dipersepsikan sesat dan kafir. Prinsip Bhinneka Tunggal Ika dan Pancasila sebagai falsafah bangsa dan negara, yang seharusnya memandu bagaimana kita hidup bersama (co-existence) dengan segala liyan, seperti menguap dan kehilangan kebermaknaannya di tengah-tengah konflik keberagamaan yang semakin mengeras.

Setara Institute pada tahun 2016, merilis sebuah laporan tahunan yang menunjukkan data yang cukup mencengangkan, bahwa telah terjadi 208 peristiwa pelanggaran kebebasan beragama dan berkeyakinan yang tersebar di 24 provinsi di Indonesia. Sementara, Komnas HAM mencatat sepanjang tahun 2016, pengaduan atas pelanggaran kebebasan beragama dan berkayakinan yang masuk ke instansinya, juga meningkat dari tahun sebelumnya, yakni 97 kasus (dari 87 kasus pada tahun 2015).

Kenyataan tersebut di atas, menyadarkan kita bahwa isu kebebasan beragama dan berkeyakinan harus tetap menjadi sorotan karena praktik intoleransi dan kekerasan atas nama agama - setidaknya dalam kurun beberapa tahun terakhir inisedang mengalami penguatan dan dalam kondisi 'pasang' di Indonesia.

Seminar ini diisi oleh tiga orang yang yang juga sekaligus tim pengabdi, yaitu M. Syafi'ie, SH., MH., tema yang disampaikan adalah realitas keberagaman di Indonesia. Arif Lukmanul Hakim, S.Fil., M.Phil., berbicara terkait dengan urgensi 
toleransi dalam keberagaman. Terakhir Dr. Despan Heryansyah, SH., MH., berbicara terkait dengan peran agama di Ruang Publik.

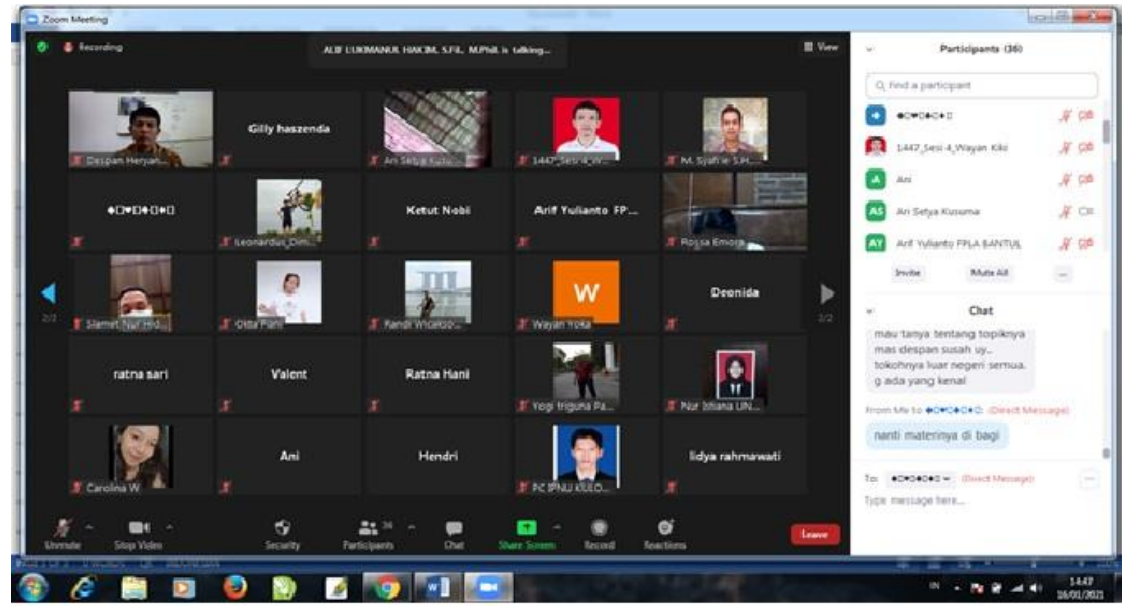

a. M. Syafi'ie, SH., MH.

Materi yang disampaikan oleh M. Syafii adalah terkait dengan realitas keberagaman di Indonesia. Menurutnya, Indonesia adalah negara yang di bangun atas keberagaman suku dan agama. Para pendiri bangsa sepakat bahwa negara ini di bangun bersama untuk menghargai semua perbedaan suku dan agama. Namun tidak dapat dipungkiri cukup banyak riak dan tantangan pembangunan bangsa dalam bidang penghargaan pada perbedaan. Sejarahnya bahkan bisa dilacak saat pendiri bangsa merumuskan dasar negara. Proses ini berdarah-darah sampai pertumpahan darah anak-anak negeri sendiri.

Tetapi tampaknya rasa curiga antar pemeluk agama masih muncul. Ada ketakutan kelompok agama lain akan melakukan Islamisasi, Kristenisasi, Katolikisasi, Hinduisasi, dan Buddhaisasi. Ini seharusnya sudah tidak ada lagi. Perdebatannya sudah selesai saat para pendiri bangsa sepakat bahwa negara ini di bangun atas dasar Pancasila. Selain itu, globalisasi yang menghilang sekat antar wilayah seharusnya menyadarkan kita bahwa semua suku dan agama terhubung. Sudah tidak relevan lagi membangun kelompok ekslusif dan tertutup. Kita perlu belajar untuk bisa hidup berdampingan dan bersama suku dan agama lain.

Indonesia sejak semula menyadari bahwa Indonesia adalah negara yang multikultural. Multikulturalisme tersebut tidak hanya pada satu aspek saja, tapi pada banyak aspek, suku, agama, bahasa, ras, dan lain sebagainya. Dari aspek agama menurutnya, indonesia adalah negara yang sangat plural dalam artian banyak agama yang tinggal di Indonesia.

1. Ada sekitar 4.200 agama di dunia (Kenneth Shouler, 2010);

2. Jajak pendapat global 2012 menyatakan bahwa 59\% dari populasi dunia adalah beragama, 36\% tidak beragama dan termasuk 13\% ateis. Ada penurunan 9\% pada keyakinan agama dari tahun 2005;

3. Di Indonesia agama besar ialah Islam, Kristen Protestan, Katolik, Hindu, Budha dan 
Khonghucu. Pemerintah Indonesia pernah melarang penganut Konghucu melaksanakan agamanya secara terbuka. Lewat Keppress No. 6/2000, Presiden Abdurrahman Wahid mencabut larangan terseb

Kekerasan atas nama agama sebanding dengan beragamnya agama dan keyakinan di dunia. Di Nigeria, kelompok Islam ekstrimis Boko Haram melakukan pembunuhan massal; Di Israel, agama Yahudi dijadikan pembenaran untuk menghabisi kaum Palestina; agama berperan atas penjajahan Eropa atas seluruh dunia. Jutaan manusia jadi korban. Sumber daya alam dikeruk demi kekayaan bangsa-bangsa Eropa; Di India, sebelum Natal 2014, sekitar 5000 keluarga diminta memeluk Hindu kembali. Mereka yang menolak diminta keluar dari India; Di Myanmar, lebih 6.000 umat Islam meninggal akibat kekejaman mayoritas Budha yang didukung junta militer, dst. Di Indonesia, kasus juga banyak, Komnas HAM menerima 23 aduan pada 2019. Laporan ini meningkat dari 2015-2018 dengan rata-rata 21 pengaduan.

Dalam rangka merespon maraknya konflik antar umat beragama di Indonesia, para pemuka agama Budha dan Islam dari 15 negara $(4 / 3 / 2015)$ membuat Yogyakarta Statement setelah pertemuan di Borobudur. Di antara isinya :

1. Menolak penyalahgunaan agama untuk mendorong diskriminasi dan kekerasan;

2. Menyerukan untuk melawan interpretasi dan aksi keagamaan yang ekstrim;

3. Mendorong peran pemerintah untuk menolak diskriminasi dan kekerasan atas nama agama;

4. Menyerukan kepada seluruh negara untuk memenuhi tanggung-jawab mereka dalam melindungi seluruh warga negaranya dari kebencian berdasarkan agama dan suku

Dalam konteks perlindungan, Indonesia adalah negara yang sangat melindungi kebebasan beragama dan berkeyakinan. Kebebasan beragama terkatagori sebagai hak yang menjadi bagian hak sipil dan politik (sipol). Hak yang terkatagori hak Sipol sering disebut sebagai hak-hak negatif (negatif rights), dimana hak kebebasan di dalamnya akan dapat terpenuhi apabila peran negara terbatasi. Apabila negara berperan intervensionis, tidak akan bisa dielakkan hakhak dan kebebasan yang diatur akan dilanggar oleh negara. Perspektif inilah yang membedakan dengan hak-hak ekonomi, sosial dan budaya, dimana negara dituntut maksimal. Negara akan melanggar HAM jika negara tidak berperan secara aktif atau berperan minus.

Adapun jaminan untuk kebebasan beragama dan berkeyakinan di Indonesia, setidaknya terdapat dalam:

1. Pasal 28I ayat 1 UUD 1945 : "Hak untuk hidup, hak untuk tidak disiksa, hak untuk kemerdekaan pikiran dan hati nurani, hak beragama, hak untuk tidak diperbudak, hak untuk diakui sebagai pribadi di hadapan hukum, dan hak untuk tidak dituntut atas dasar hukum yang berlaku surut adalah hak asasi manusia yang tidak dapat dikurangi 
dalam kondisi apapun."

2. Pasal 28E ayat 1 UUD 1945 : "Setiap orang bebas memeluk agama dan beribadat menurut agamanya, ...."

3. Pasal 28E ayat 2 UUD 1945 : "Setiap orang berhak atas kebebasan meyakini kepercayaan, menyatakan pikiran dan sikap sesuai dengan hati nuraninya".

4. Pasal 29 ayat 2 UUD 1945 : "Negara menjamin kemerdekaan tiap-tiap penduduk untuk memeluk agamanya masing-masing dan untuk beribadat menurut agamanya dan kepercayaannya itu."

5. Pasal 22 ayat 1 UU No. 39 tahun 1999 tentang HAM : "Setiap orang bebas memeluk agamanya masing-masing dan beribadat menurut agamanya dan kepercayaannya itu".

6. Pasal 22 ayat 2 UU No. 39/1999 : "Negara menjamin kemerdekaan setiap orang memeluk agamanya masing-masing dan beribadat menurut agamanya dan kepercayaannya itu."

7. Cek juga di Pasal 18 Deklarasi Universal Hak Asasi Manusia dan Kovenan Hak Sipil dan Politik (halaman 160-161)

b. Arif Lukmanul Hakim, S.Fil., M.Phil.,

Materi yang disampaikan oleh Arif Lukmanul Hakim adalah terkait dengan urgensi toleransi dalam keberagaman. Ia memulai materinya dengan mengatakan, Semboyan Bhineka Tunggal Ika begitu kental tersemat dalam kehidupan masyarakat Indonesia. Hal ini merujuk pada kehidupan masyarakatnya yang multi etnis dan tersebar dari Sabang hingga Merauke. Secara geografis, Indonesia merupakan negara kepulauan yang memiliki banyak ragam suku, ras, bahasa dan agama atau disebut juga dengan pluralitas.

Pluralitas menjadi sebuah realita dan mesti diterima sebagai kekayaan nasional bangsa Indonesia. Belajar tentang pluralitas di Indonesia berarti belajar tentang kemajemukan masyarakat yang terdiri dari keragaman suku bangsa, agama, ras, pekerjaan, dan lainnya yang tentunya memiliki perbedaan dan berbagai permasalahan yang dihadapi dalam masyarakat di Indonesia.

Terdapat beberapa agama dan banyak aliran kepercayaan yang diakui di Indonesia, sehingga menjadi hal yang lumrah jika melihat upacara sembahyang yang berbeda-beda. Ada 6 agama yang diakui di Indonesia yaitu Islam, Katolik, Kristen, Buddha, Hindu, dan Konghucu. Selain itu ada aliran kepercayaan seperti kejawen yang dianut masyarakat Jawa dan di daerah lain di Indonesia.

Di kalangan umat beragama senantiasa berkembang pandangan yang bercorak partikular, yaitu klaim kebenaran agama (religious truth claim). klaim ini berarti menegasikan (to exclude) agama lain, adanya monopoli kebenaran yang eksklusif-konservatif.

Menurutnya, Indonesia sebagai negara hukum yang demokratis sangat menjunjung tinggi kebebasan, baik itu kebebasan berpendapat maupun kebebasan beragama dan berkeyakinan seluruh warga negara. Dalam UUD 1945 
Pasal 29 ayat (2) disebutkan bahwa, "Negara menjamin kemerdekaan tiap-tiap penduduk untuk memeluk agamanya masing-masing dan untuk beribadat menurut agamanya dan kepercayaannya itu". Dalam UUD 1945 Pasal 28 E juga menyebutkan,

"1) Setiap orang bebas memeluk agama dan beribadat menurut agamanya; 2) Setiap orang berhak atas kebebasan meyakini kepercayaan, menyatakan pikiran dan sikap, sesuai hati nuraninya; dan 3) Setiap orang berhak atas kebebasan berserikat, berkumpul, dan mengeluarkan pendapat".

Tidak hanya itu, jaminan kebebasan beragama dan berkeyakinan juga kembali diteguhkan dalam UU No. 39 Tahun 1999 tentang Hak Asasi Manusia dan UU No. 12 Tahun 2005 tentang Ratifikasi Konvenan Internasional Hak-Hak Sipil dan Politik. Artinya, kita sebenarnya sudah memiliki landasan konstitusional dan perundangan bagi terpenuhinya hak kebebasan beragama dan berkeyakinan. Hanya saja faktanya, amanat konstitusi dan perundangan tersebut sakti di atas kertas, tapi lumpuh dan tak berdaya dalam kenyataan. Dikatakan demikian, sebab masih banyak ditemukan peraturan-peraturan di bawahnya yang restriktif dan bertentangan dengan semangat konstitusi. Bahkan, tidak jarang justru pemerintah yang mengingkari konstitusi itu sendiri. Negara, melalui aparatur pemerintahnya, acapkali terlibat sebagai aktor yang ikut merampas hak kebebasan beragama dan berkeyakinan kelompok-kelompok minoritas, terutama karena tak mampu menghadapi desakan dan tuntutan dari mayoritas. Tak mengherankan, jika kasus pelanggaran kebebasan beragama dan berkeyakinan terus terjadi dan terjadi terus karena "direstui" dan "disponsori" oleh negara dan pemerintah.

Salah satu sikap yang dapat menangkal hadirnya sikap yang dapat memunculkan gesekan antar pemeluk agama tersebut adalah sikap toleransi. Sikap toleransi sendiri memiliki akar yang kuat dalam Islam,

1. Ketika Nabi Muhammad hijrah ke kota Madinah, Nabi melihat kenyataan adanya pluralitas agama (Yahudi, Nasrani, Islam)

2. Pasal 25 Piagam Madinah menyebutkan bahwa bagi orang-orang Yahudi agama mereka dan bagi orang Islam agama mereka.

3. Pasal 20 Piagam Madinah mengisyaratkan bahwa orang-orang musyrik atau kafir Madinah tidak dinyatakan sebagai musuh kaum Muslimin.

4. Kebebasan beragama pada masa Nabi Muhammad SAW juga ditunjukkan dengan adanya kebebasan dalam melakukan propaganda keagamaan

5. Hubungan Sosial, kemasyarakatan dan interaksi sehari-hari yang setara.

Islam mengajarkan agar umat Islam berbuat baik dan bertindak adil kepada siapapun yang tidak memerangi umat Islam karena agama yang dianut. Islam mengutamakan terciptanya suasana perdamaian, hingga timbul rasa kasih sayang di antara umat Islam dengan umat beragama lain .Kerjasama yang baik antara umat Islam dan umat beragama lain tidaklah menjadi halangan dalam Islam. Islam mengajarkan untuk tidak menjelek-jelekkan kelompok lain, karena 
jangan-jangan, kelompok yang kita jelek-jelekkan lebih baik dari yang menjelekjelekkan.

Disamping itu, toleransi dapat dipupuk dengan berbagai macam cara, cara yang paling umum digunakan adalah dengan dialog antar agama. Denganb berdialog, maka pemeluk agama akan semakin mengenal, dan dengan saling mengenal maka konflik dapat dihindarkan. Adapun model dialog yang dapat digunakan diantaranya meliputi:

1. Dialog parlementer (parliamentary dialogue) yang melibatkan tokoh-tokoh umat beragama sedunia. misalnya world's parliament of religions (1980-1990an) dan conference on religions and peace, dan the world congress of faiths, wcrp, dll. Tujuannya mengembangkan kerjasama dan perdamaian di antara umat beragama.

2. Dialog kelembagaan (institutional dialogue) yang melibatkan organisasiorganisasi keagamaan. Tujuannya mendiskusikan dan memecahkan persoalan keumatan dan mengembangkan komunikasi di antara organisasi keagamaan (PGI, Walubi, KWI, parisadha hindu dharma, NU, Muhammadiyyah, Persis dll).

3. Dialog teologi (theological dialogue). tujuannya adalah untuk membahas persoalan-persoalan teologis-filosofis. memberikan pemahaman mengenai konsep teologis masing-masing agama. membangun pemahaman sesuai yang dikehendaki agama masing-masing, dan menghindari pemahaman yang subjektif.

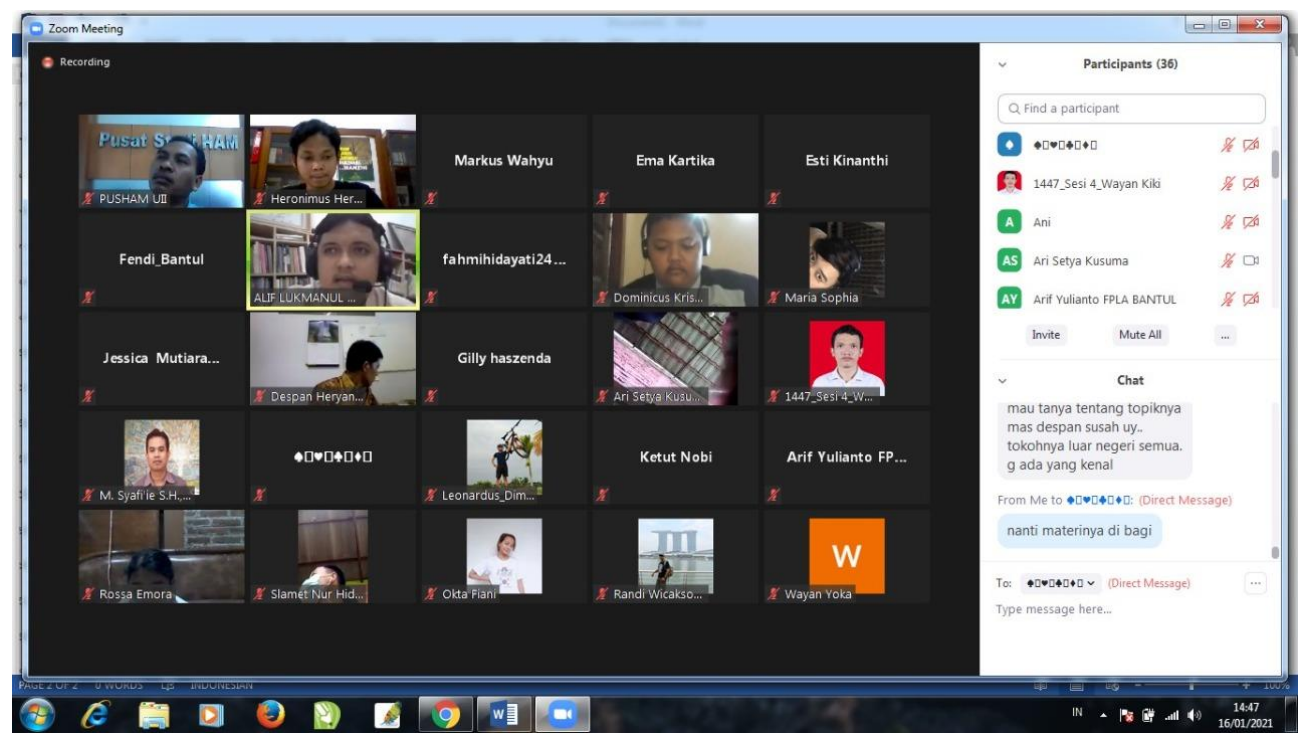

\section{c. Dr. Despan Heryansyah, SH., MH.}

Despan Heryansyah menyampaikan materi terkait dengan peran agama di ruang publik. Ini merupakan masalah yang paling mendasar di Indonesia saat ini, yaitu bagaimana menempatkan agama di ruang publik. Despan mengawali materinya dengan menceritakan apa yang terjadi di Eropa lalu mengkontekskannya dengan situasi Indoensia saat ini. 
Kira-kira dua setengah abad silam, Masyarakat menghasilkan suatu cara untuk mengakhiri absolutisme agama dan konflik-konlik agama. Yaitu dengan memisahkan agama dan politik dengan mengurung agama di dalam kebungkaman ruang privat. Pemisahan itu harus dilihat sebagai sebuah prestasi peradaban yang penting yang memungkinkan masyarakat memiliki kebebasannya untuk menggunakan rasio di dalam ruang publik tanpa sensor dari keyakinan-keyakinan agama.

Pemisahan agama dan politik itu disebut dengan istilah sekularisasi. Istilah ini kerap disalahpahami dengan istilah serupa yaitu : sekularisme. Kata sekular kurang disukai bahkan dibenci oleh kelompok agama tertentu karena dianggap bertentangan dengan iman. Kata itu kemudian dicampuradukkan dengan kata sekularisasi dan sekularisme, sehingga juga tidak disukai bahkan diharamkan. Sebaiknya kita memendam emosi sejenak dan mencari lebih jauh perbedaan antara kedua istilah tersebut.

Di Barat, istilah sekularisasi secara luas diartikan sebagai proses pemisahan gereja dan negara. Mengingat klaim agama atas kemutlakan dan totalitasnya yang terwujud dalam masyarakat Barat tradisional, sekularisasi dapat diartikan sebagai proses emansipasi tatanan politis dari dominasi dan determinasi agama.

Mengapa Barat mengambil jalan sekularisasi untuk peradabannya? Sekularisasi adalah respon terhadap sebuah problem yang berabad-abad mencengkeram manusia: absolutisme agama. Sebagai sistem dunia agama dan simbolnya melekat pada kekuasaan politis dan memegang monopoli interpretasi atas apa yang wajib dilakukan dan dipikirkan indovide untuk keselamatannya di dunia dan akhirat. Jika negara melebur dengan agama, norma-norma hukumnya disakralisasi dan negara pun menjadi aparatus yang mengurusi keberanaran dan jalan keselamatan yang dipilih rakyatnya.

Persoalan sesungguhnya tidak terletak pada klaim kemutlakan kebenaran iman itu sendiri, yang memang wajar jika seseorang yang beriman sebagai orientasi nilainya, melainkan penggunaan klaim iman itu dalam ruang publik. Dampaknya ada dua: memberangus pikiran, menciptakan konflik antara iman kita dan iman mereka. Lewat sekularisasi, masyarakat barat menemukan jalan keluar dari patologi tersebut (absolutisme agama), dengan menarik agama dari posisi publiknya ke dalam ruang privat.

Sekularisasi membantu masyarakat modern untuk menempatkan agama pada posisinya yang luhur, yaitu sebagai hubungan pribadi manusia dengan yang ilahi, sehingga orang beragama bukan karena agama itu mengokohkan identitas sosial atau eksistensi politik seseorang, melainkan karena beriman dalam agama itu merupakan hubungan yang ilahi.

Sejarah Barat mengalami semacam "Dialektika Sekularisasi": Pemisahan agama dan negara yang membawa pada sukses emansipasi dari absolutisme agama itu mengambil konsekuensi radikalnya dalam bentuk lain, yaitu doktrin 
yang sama sekali menolak dan dengan sengit menyingkirkan segala iman religius dan alasan religius dalam kehidupan bersama secara politis. Sosok doktriner dan ideologis itulah yang kita sebut "Sekularisme". Dalam pandangan sekularisme agama dianggap irrasional, maka tidak berhak bersuara di ruang publik. Jika dalam agama ada fanatisme dan radikalisme, di sini kita dapati antagonisme yang juga fanatisme dan radikalistis.

Di dalam sekularisasi yang ingin membangun ruang publik yang propluralisme, dalam sekularisme malah berbalik menjadi inteoleransi terhadap alasan-alasan religius apapun. Negara liberal sekular ingin mempertahankan netralitasnya dihadapan berbagai orientasis nilai yang majemuk dalam masyarakat, tetapi ini dilakukan sering dengan ongkos memblokade alasanalasan religius sebagai privat dan mengancam kepentingan keseluruhan.

Negara hukum modern di dunia ini, menghadapi dua macam jebakan yang dihasilkan lewat sekularisasi. Negara masuk ke dalam jebakan sekularisme jika menyingkirkan setiap alasan religisu yang diyakini oleh para warganegaranya yang beriman. Namun diujung lain menganga jebakan radikalisme agama, jika negara menerima begitu saja alasan religius dan menjadikannya regulasi publik. Negara hukum demokratis harus piawai berselancar dalam tegangan kedua sisi tersebut tanpa terjerembab ke dalamnya, karena sebuah masyarakat majemuk diancam dari kedua sisi gulita itu.

Diskursus mengenai masyarakat "post-sekular" perlu ditempatkan dalam konteks kedua jebakan di atas sebagai jalan tengah. Filsuf Jerman kontemporer, Jurgen Habermas, menjelaskan post-sekularitas suatu masyarakat sebagai keterbukaan komunikasi dan dialog. Dalam kondisi itu para warganya yang menolak agama di ruang publik atau kaum sekular harus bersedia mendengarkan kontribusi rekan-rekannya yang religius, karena kerap kali bdalam kepompong alasan-alasan mereka yang partikular terkandung kebenaran yang lebih umum. Sebaliknya, para warga negara yang beriman harus belajar dari para warga negara sekular atau yang beriman lain untuk mengarahkan alasan mereka yang absolut namun partikular itu kepada rasionalitas publik.

Menurut Habermas, kelompok-kelompok agama harus berupaya menerjemahkan bahasa teologis mereka yang dianggap partikular dalam masyarakat majemuk itu ke dalam ungkapan-ungkapan yang dapat diterima secara rasional oleh publik yang lebih luar daripada agama itu. Bagi umat beriman, ini merupakan tantangan yang pelik karena mereka harus merelatifkan posisi mereka dihadapan agama-agama lain dan dihadapan para warga sekular tanpa merelatifkan inti dogmatis agamanya sendiri. Jadi, seorang muslim atau kristen tetap berpegang pada kebenaran imannya, meski diruang publik ia harus bersikap moderat dengan lebih mengutamakan kepentingan publik yang lebih luar. Kita bisa menyebut orang-orang semisal Gus Dur, Romo Mangun, Gandhi, 
Prof Amin, sebagai orang-orang beriman yang tetap membawa imannya dalam ruang publik namun menginklusifkannya menjadi bahasa publik.

Jika post sekularisme dimaknai sebagai kembalinya agama ke ruang publik semata, maka kondisi yang berbeda terjadi di Indonesia. Di sini agama tidak pernah pergi jadi tidak harus kembali. Jika di Barat pernah diwarnai dengan absolutisme agama lalu muncul sekulerisme, di Indonesia tidak demikian. Agama tidak pernah menjadi absolut, dengan demikian juga tidak perlu menjadi sekuler. Di negeri ini justeru terlalu banyak hal dikaitkan dengan agama, dan terlalu sedikit hal yang berjarak darinya. Namun post-sekularisme juga menemukan singgungannya.

Inti post sekularisme sebenarnya proses belajar antara agama dan sekularitas dalam masyarakat majemuk. Karena itu, dalam masyarakat serba agama seperti Indonesia, tidaklah tepat memahami post sekularisme sebagai penguatan kembali peran publik agama, karena agama, sekurangnya secara institusional sudah terlalu kuat disana. Jika di Barat sekularitas di tantang untuk belajar mendengarkan agama kembali, di Indonesia justeru sebaliknya: agama ditantang untuk belajar dari sekularitas agar tidak menyepelekan kemanusiaan dan dimensi-dimensi profan kehidupan.

\section{Dialog Antar Penganut Agama}

Dialog ini diadakan dalam rangka mendengarkan perspektif beberapa agama terkait dengan toleransi. Dialog diselenggarakan pada tanggal 30 Januari 2021, pukul 13.00-17.00 WIB secara daring melalui aplikasi Zoom. Pemuda memiliki peran penting dalam sejarah Indonesia. Saat nusantara di bawah pemerintahan kolonial Belanda sudah muncul gerakan pemuda lintas etnis dan agama mengusung persatuan dalam Sumpah Pemuda 28 Oktober 1928. Di perdebatan sidang Badan Penyelidik Usaha-Usaha Persiapan Kemerdekaan Indonesia (BPUPKI) pertama (29 Mei - 1 Juni 1945) dan kedua (10-17 Juli 1945) menyetujui bahwa dasar negara merdeka berdiri di atas keberagaman suku dan agama. Bahkan hasil sidang perumusan dasar negara yang disetujui tanggal 18 Agustus 1945 menyebutkan Negara Indonesia merdeka berlandaskan pada Pancasila dan Bhinneka Tunggal Ika. Argumentasinya Negara Indonesia yang terdiri dari beragam budaya dan agama sudah ada sebelum Indonesia merdeka. Setiap orang Indonesia memiliki sumbangan bagi kemerdekaan dan pembangunan bangsa. 


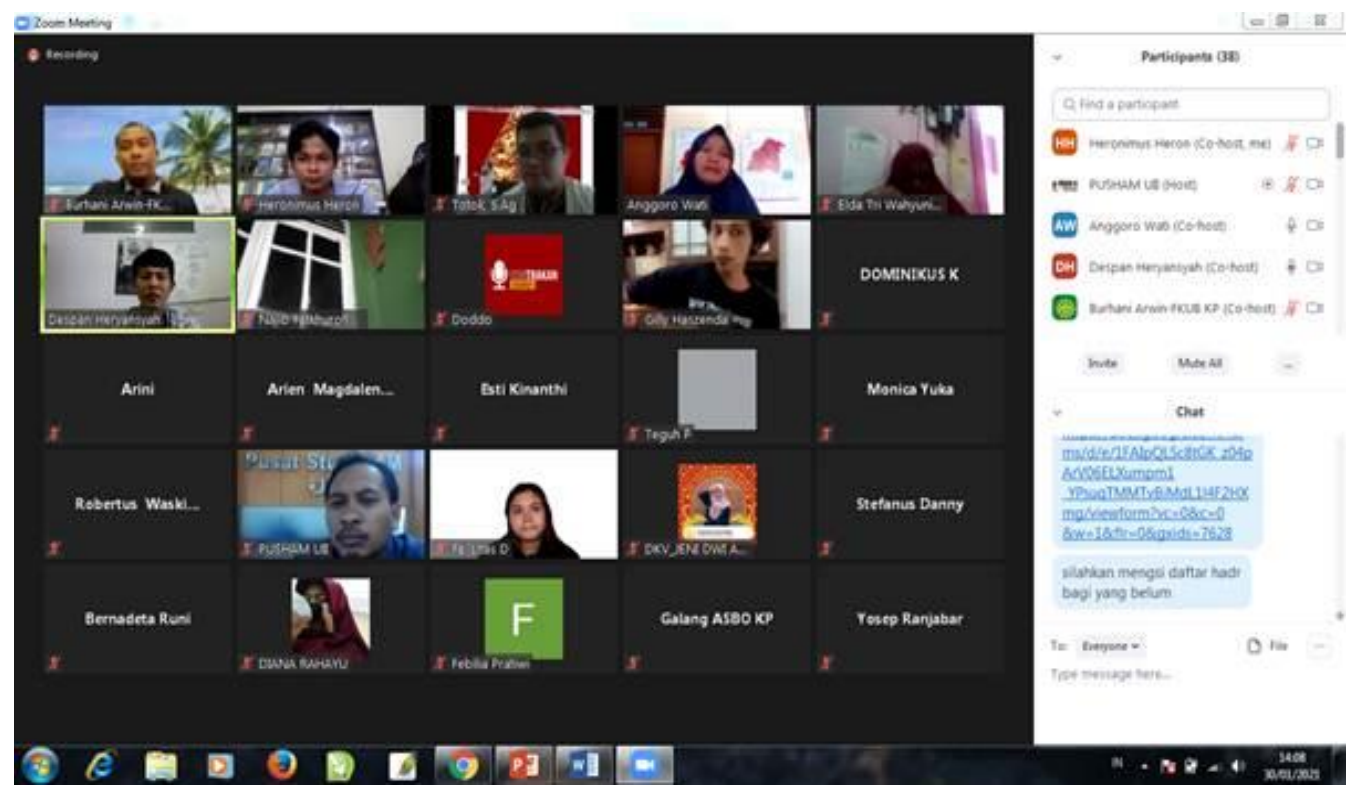

Persatuan dan kebersamaan sebagai anak bangsa yang berbeda etnis dan agama perlu terus dirawat. Tidak cukup hanya ada dalam buku teks sejarah bangsa tetapi harus di tanam dalam diri dan diwujudkan dalam tindakan bersama. Tentu pandangan ini tidak sedang menyamakan setiap teologi agama-agama, namun ada aspek sosial dan kemanusiaan dari ajaran agama yang bisa diimplementasikan dalam tindakan nyata bersama sebagai pemuda-pemuda agama.

Para pemuda saat ini menghadapi tantangan dari beragam informasi yang bisa menjurus pada upaya saling menghujat antar pemeluk agama. Kanal-kanal informasi mengenai ajaran agama muncul di banyak platfom atau channel atau akun media sosial. Tidak jarang ada akun media sosial digunakan untuk menyebarkan kebencian atas nama agama kepada agama atau ajaran lain. Tentu tindakan ini sangat disesalkan karena bisa merusak hubungan antar umat beragama.

Para pembicara dalam dialog Pemuda Merajut Persatuan Dalam Membangun Perdamaian yang dimoderatori oleh Dominikus Kristiyanto (Orang Muda Katolik, Paroki Wates) berasal dari Pemuda Theravada Indonesia (Patria), Nasyiatul Aisyiyah (NA) dan FKUB Kulon Progo. Adapun pembicaranya ialah:

Pembicara pertama ialah Anggoro Wati, S.PdI dari Forum Pemuda Lintas Agama (FPLA) perwakilan Nasyiatul Aisyiyah akan berbicara mengenai ajaran agama yang digunakan sebagai landasan membangun kehidupan bersama sebagai umat beragama. Apa yang perlu dilakukan saat ada teman yang masih antipati atau sinis dengan gerakan membangun kerukunan dan perdamaian umat beragama? Apa cara yang dilakukan supaya tidak terjebak dalam kedangkalan informasi yang bisa memecah belah hubungan antar agama di media sosial? Anggoro menjelaskan bahwa pemuda memiliki peranan penting dalam sejarah Indonesia. Hampir semua peristiwa di Indonesia hampir selalu disertai dengan peran pemuda, bahkan kemerdekaan tahun 1945 juga atas peran pemuda yang cukup besar. Namun sayangnya, belakangan ini tidak sedikit pemuda yang justeru terlibat dalam banyak konflik, termasuk konflikn antar umat beragama. Hal ini terjadi salah satunya 
karena kurang terbuka dalam melakukan dialog dengan pihak lain yang berada dari luar agamanya. Sejatinya, semua orang dapat terbuka berinteraksi dan saling mengenal dengan orang lain yang berasal dari identitas yang berbeda. Dengan begitu mereka akan saling mengenal satu sama lain, sehingga konflik dapat dihindari sedini mungkin.

Setiap agama di dunia ini mengajarkan tentang toleransi termasuk agama Islam. Toleransi tidak saja diajarkan namun juga dicontohkan oleh kehidupan Nabi saat berada di Mekan maupun Madinah. Nabi dapat hidup berdampingan dengan aman dan tenteram bahkan bersama dengan orang-orang kafir sekalipun. Mereka saling mendukung dan membantu apabila suatu ketika ada serangan dari kelompok atau suku lain. Hal ini secara tertulis dapat pula ditemukan dalam apa yang kita kenal dengan piagam madidah.

Pembicara kedua ialah Totok dari Pemuda Theravada Indonesia Kulon Progo. Totok akan berbicara mengenai ajaran agama yang menjadi pegangan membangun hubungan pemuda antar agama. Apa yang dilakukan saat ada teman yang masih antipati atau sinis dengan gerakan membangun kerukunan dan perdamaian umat beragama? Apa yang dilakukan supaya tidak terjebak dalam kedangkalan informasi di media sosial yang dapat memecah-belah hubungan umat beragama?

Menurut Totok, fitrahnya setiap manusia di dunia ini diciptakan beragam oleh sang pencipta. Oleh karena itu, orang yang menolak atau membenci perbedaan sesungguhnya sedang melawan kehendak atau fitrah alam semesta. Orang yang demikian sudah dipastikan akan kalah. Oleh karena perbedaan adalah fitrah, maka memiliki sikap toleransi sejatinya adalah kewajiban bagi setiap orang. Toleransi adalah satu-satunya jalan yang dapat digunakan untuk mengakui adanya fitrah tersebut. Sayangnya, hari ini kita banyak termakan oleh hoaks sehingga mudah sekali dipecah belah oleh orang lain atau pihak lain yang mengambil keuntungan tertentu dari konflik yang terjadi.

Dalam ajaran Buddha diajarkan untuk EHIPASSIKO: cek, lihat, buktikan, berpikir kritis terhadap sesuatu.

1. Siapa yang membuat?

2. Untuk kepentingan apa?

3. Siapa yang untung?Siapa yang dirugikan?

4. Cari sumber pembanding yang terpercaya

5. Apa dampaknya jika disebarkan?

Kemajuan Teknologi Informasi adalah sebuah keniscayaan yang tak mungkin kita hindari. Apakah kita mau diperbudak oleh teknologi informasi atau kita bisa memanfaatkan teknologi informasi ini tergantung bagaimana moral dan kebijaksanaan kita. Masih dalam konteks agama Budha, mengajarkan dalam Kitab Sutta Pitaka Dighanikaya 16 Mahaparinibbana Sutta:

1. Sering bermusyawarah akan memperoleh kemajuan

2. Mengutamakan dan menjaga perdamaian

3. Menetapkan peraturan baru tanpa meniadakan peraturan lama 
4. Menghargai sesepuh, orang-orang berjasa terdahulu sebagai penasihat

5. Melindungi wanita dan anak-anak

6. Menghormati dan menjaga tempat-tempat suci

7. Menghormati dan memberikan sokongan kepada orang-orang suci

Pembicara ketiga dari Forum Kerukunan Umat Beragama Kulon Progo

(FKUB). Perwakilan FKUB akan berbicara mengenai pentingnya kerukunan umat beragama di Kulon Progo, dan potensi serta peran pemuda dalam upaya menjaga kerukunan umat beragama di Kulon Progo. Beliau menceritakan tentang bagaimana situasi kerukunan di Kulon Progo. Bahwa selama ini Kulon Progo adalah daerah yang terbilang aman dan toleransinya tinggi. Namun demikian, kita tidak bisa terlena begitu saja dengan peristiwa yang ada saat ini. Pembangunan Bandara di Kulon Progo yang sudah selesai hingga saat ini, memungkinkan untuk banyak orang atau pihak yang tertarik pindah ke Kulon Progo. Dapat diperkirakan, dalam beberapa tahun ke depan Kulon Progo akan menjadi daerah perkotaan. Dengan demikian, akan banyak sekali persinggungan antara banyak identitas, salah satunya adalah identitas agama. Persinggungan ini akan menjadi kekuatan apabila masyarakat telah memiliki toleransi sebelumnya. Namun, akan berbahaya apabila masyarakat tidak memiliki jiwa toleransi sehingga dengan mudah bisa dipecah belah oleh kelompok lain. Terlebih dengan mudah dimanfaatkan untuk kelompok politik untuk kepentingan politik praktis. Oleh karena itu, dalam konteks ini peran pemuda sangat dibutuhkan, agar paling tidak para pemuda dapat saling berinteraksi dengan begitu konflik sedini mungkin dapat dihindari.

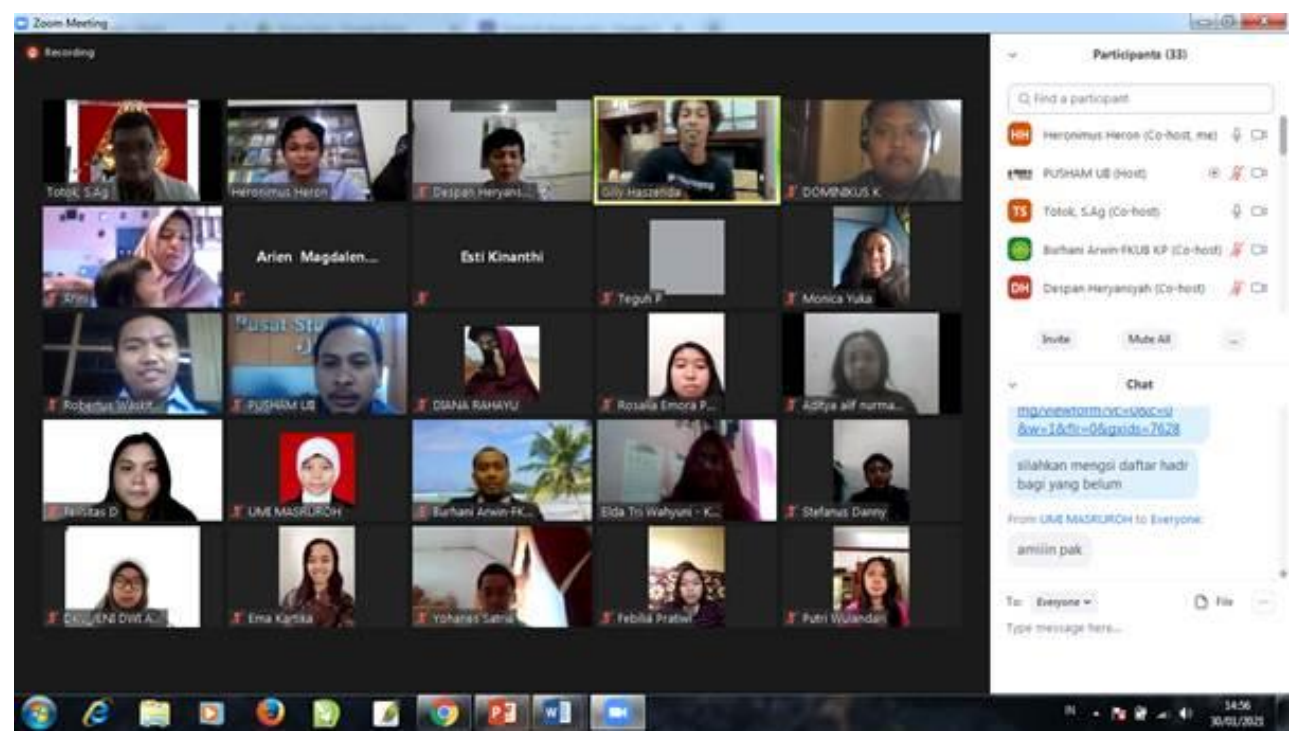

\section{Evaluasi Kegiatan}

Setelah semua kegiatan berhasil diselenggarakan, diadakan evaluasi untuk mengetahui sejauh mana tujuan kegiatan dapat dicapai dan apa yang menjadi pelajaran untuk kegiatan pengabdian pada masa yang akan datang. Adapun hasil dari evaluasi tersebut adalah sebagai berikut: Pertama, semua kegiatan berhasil diselenggarakan sesuai dengan perencanaan, yaitu pelatihan bagi anggota FPLA 
dan Diskusi/Dialog antar agama. Kedua, pandemi covid19 telah mengubah banyak pola pelatihan, terutama karena diselenggarakan secara online. Oleh karena sebelumnya kegiatan pelatihan hampir selalu diselenggarakan secara offline (langsung) sehingga ditemua beberapa kendalam dalam praktek pelatihan online, yaitu terdapat gangguan teknis. Ketiga, kegiatan serupa perlu untuk direplikasi di daerah lain karena penyebarluasan nilai-nilai toleransi adalah kebutuhan setiap daerah.

\section{Kesimpulan}

Kesimpulan yang kami ambil dalam pengabdian ini adalah sebagai berikut:

1. Melalui kegiatan ini, maka setidaknya ada dua capaian yang diperoleh bersama dengan mitra, yaitu: Pertama, Forum Pemuda Lintas Agama (FPLA) dapat mengaktifkan kembali kegiatannya dan memperkuat jaringan dengan instansi atau organisasi lain. Selama ini, memang ada kegiatan yang diselenggarakan, namun masih cukup terbatas dari aspek kuantitasnya. Kedua, transfer pengetahuan khususnya menganai toleransi kepada anggota FPLA, terutama anggota FPLA baru.

2. Dalam dua kegiatan yang telah diselenggarakan, mitra dalam hal ini FPLA Kulon Progo memiliki dua kontribusi: 1) menyiapkan teknis kegiatan serta menghubungi peserta, karena peserta adalah anggota baru FPLA; 2) menjadi membuat flyer dan menyebarluaskannya kepada jejaring sosial.

3. Adapun hambatan dan kendala yang ditemui pada saat menyelenggarakan kegiatan yaitu: 1) karena masih dalam kondisi pandemi, maka rapat koordinasi hanya dapat dilakukan secara daring. Ini cukup menyulitkan terutama dalam hal mencari dan menghubungi peserta; 2) kegiatan yang menggunakan aplikasi zoom kadang kala mendapatkan gangguan teknis jaringan, terutama karena beberapa peserta tinggal di daerah dalam Kulon Progo. 


\section{Daftar Pustaka}

Azyumardi Azra, Pergolakan Politik Islam: dari Fundamentalisme, Modernisme, hingga PostModernisme, (Jakarta: Paramadina, 1996).

Bahtiar Efendi, Islam dan Negara: Transformasi Pemikiran dan Praktik Politik Islam di Indonesia (Jakarta: Paramadina, 1998).

Dedy Djamaluddin Malik dan Idi Subandy Ibrahim, Zaman Baru Islam di Indonesi: Pemikiran $\mathcal{E}$ Aksi Politik Abdurrahman Wahid, M. Amin Rais, Nurcholish Madjid, Jalaluddin Rahmat. Bandung: Zaman Wacana Mulia, 1997).

John L. Esposito dan John O. Voll, Demokrasi di Negara-negara Muslim: Problem dan Prospek, terj. Rahmani Astuti (Bandung, Mizan, 1999).

Mujtaba Hamdi, "Sang Liyan dan Kekerasan: Kasus Penyerangan Kampus Mubarak Jemaat Ahmadiyah Indonesia, Kemang-Bogor-Jawa Barat", yang terhimpun dalam buku "Politisasi Agama dan Konflik Komunal".

Nurcholish Madjid, Islam Doktrin dan Peradaban (Jakarta: Paramadina, 1999).

Zainal Abidin, "Ancaman terhadap Kebebasan Beragama dan Berkeyakinan" sebuah prolog dalam buku "Refleksi Keberagaman Agama: Hukum Sesat dan Menyesatkan Hukum", YLBHI, Jakarta, 2009. 